\title{
Key Role of Education in the Framework of Achieving the Goals of Sustainable Economic Development
}

\author{
A.A.Usmanova, S.A.Usmanov
}

\begin{abstract}
The article is devoted to the goals of sustainable development aimed at achieving economic growth in the world, creating conditions for stimulating the economy in order to expand the boundaries of business activity of young people, achieve the principles of competitiveness and the demand for specialists in the labor market. It is proved that the favorable criteria for economic achievements are the level of education of the population, its mobile susceptibility to critical thinking and self-motivation. Attention is focused on the key importance of education necessary for sustainable development, ensuring the formation of citizens' knowledge, skills, attitudes and values for their active participation in social and economic life.
\end{abstract}

Keywords: economic sustainable development, innovative technologies, modular education system, sustainable development,

\section{INTRODUCTION}

The 70th UN General Assembly, as part of the Summit on Sustainable Development, adopted the 2030 Agenda for Sustainable Development, which included the new 17 Global Sustainable Development Goals (SD). According to UN leaders, the adoption of the official document "Transforming Our World: An Agenda for Sustainable Development for the Period until 2030" [1] marks a new historical stage in the transition to SD of the entire world community. The Sustainable Development Goals (SDGs) were a continuation of both the benchmarks of all previous UN documents on sustainable development, and the Millennium Development Goals, which identified only eight international development goals as priority ones and which were adopted by UN member states in 2000 and should were mostly completed by 2015.

Emphasizing the problems, I would like to dwell on the relationship of the fourth and eighth global goals of SD. The eighth goal is to promote sustained, inclusive and sustainable economic growth, full and productive employment and decent work for all. The implementation of this task involves creating opportunities for the population, especially youth, in decent employment, attracting investment and creating

Revised Manuscript Received on November 15, 2019.

* Correspondence Author

Azizakhon Abdullajonovna Usmanova*, Associate Professor, Department of "Social and humanitarian disciplines" Gubkin Russian State University of Oil and Gas (National Research University) in Tashkent, Tashkent, the Republic of Uzbekistan. Email: Aziza-64@mail.ru

Sardorbek Abdullayevich Usmanov, Student, Faculty "International relations" University of world economy and diplomacy, Tashkent, the Republic of Uzbekistan. Email: SardorUsmanov@mail.ru

(c) The Authors. Published by Blue Eyes Intelligence Engineering and Sciences Publication (BEIESP). This is an open access article under the CC BY-NC-ND license (http://creativecommons.org/licenses/by-nc-nd/4.0/) high-quality jobs in the regions. Ensuring sustainable economic growth of society provides for the creation of conditions to stimulate the economy without harming the environment, the expansion of youth business centers that can prove their strength and competitiveness in the international market, as well as the development of human capital. Ensuring the implementation of the eighth goal is not possible without "achieving an inclusive and equitable quality education and encouraging lifelong learning for all" (Goal No. 4 of SD). It is presented in the UN and UNESCO programs even as a new concept of education, which is seen in transforming the lives of people, especially youth, through education, and its role is recognized as the main driving force of development and in achieving other proposed goals [2] The prioritization of Goal No. 4 in the SDGs does not at all mean that the other goals adopted are not related to education. One way or another, they are closely related to education and are already entering or will enter the subject field of education for sustainable development (ESD). It became quite obvious that a new model of civilization development of the III millennium can be formed only with the help of its most important subsystem - education, as indicated by the "historical synchronism" of the beginning of the transition to SD and the implementation of the decade of ESD, which thereby appear as a priority mechanism for the transition to the "global sustainability".

\section{REVIEW CRITERIA}

SD is usually viewed from the perspective of a systemic relationship between the economy, ecology and the social sphere ("sustainable triad"). These are the priority areas of activity that were selected during the formation of the concept of SD, although it is clear that now these priorities of SD are much larger and they are changing over time. The mentioned priorities of the SD concept also affect education, therefore, the call to focus on the formation of a systematic, but for some reason only "three-dimensional" (environmental - economic - social) vision of this process already looks like a kind of restriction on the further development of the concept of SD [3]. Moreover, given the special importance of the educational area, it should expand the "sustainable triad", distinguishing itself from the general social sphere as a very important priority mechanism for the activity of the world community, mainly through which a sustainable future will be formed.

Published By:

Blue Eyes Intelligence Engineering

\& Sciences Publication

(C) Copyright: All rights reserved.

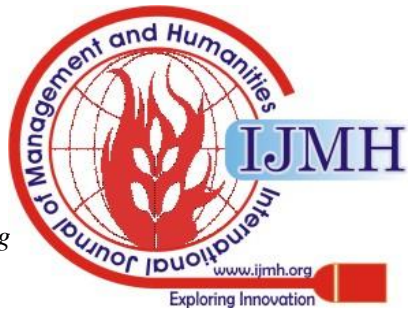


Education is usually referred to as the social sphere. However, this is not entirely accurate, since as a form of activity, education acts as an informational interaction of the individual, the economic component of society and nature, in principle covering all spheres of human activity [4, p. 123]. It applies, at a minimum, to all the components of the UR-triad.

In the "Information Note on the World Conference on Education for Sustainable Development in 2014", it was noted that education for sustainable development (ESD) allows young people to acquire the values, competencies, skills and knowledge necessary to build the future in accordance with the goals of sustainable development [5, p. 2-3]. ESD involves the integration of such education, the widespread use of such facilitating skills and teaching and teaching methods that will be aimed at developing a critical understanding and self-motivation of a person for life in the interests of a sustainable economic future.

\section{RESULT AND DISCUSSION}

The signing by the heads of educational institutions of a number of countries of the world of the mentioned Obligation to promote teaching methods that will help young people acquire the knowledge and skills needed to create more sustainable economic growth in society stimulate research into problems in this area and they apply to all universities in the world. It is understandable that, thanks to the "sustainable educational movement", the acceleration and expansion of the scale of economic well-being is possible. Education is a key tool for Uzbekistan's transition to sustainable development, ensuring the formation of citizens' knowledge, skills, attitudes and values necessary for their active participation in the socio-economic life of the country.

The system of continuing education in the framework of sustainable development in Uzbekistan is carried out in accordance with the Strategy of Action for the five priority areas of development of the Republic of Uzbekistan in 2017-2021, Decrees of the President of the Republic of Uzbekistan Sh. M. Mirziyoyev "On measures for the further development of the higher education system" (2017) , "On measures to further expand the participation of industries and sectors of the economy in improving the quality of training of specialists with higher education" (2017), "On additional measures to improve the quality of images at higher educational institutions and ensuring their active participation in large-scale reforms being implemented in the country"(2018) and others. However, the measures taken to implement the UN Economic Commission for Europe (ECE) Strategy for Education for Sustainable Development (2005) do not lose their relevance), the introduction of new programs and a consistent increase in the level of environmental knowledge of the population, especially youth, at all stages of the educational process in Uzbekistan (2018) [6]. Currently, the Concept on ESD is implemented in the system of formal (taking into account state educational standards) and non-formal (based on extracurricular, optional and extracurricular activities) training, on the basis of ESD action plans at the Ministries of Public, Higher and Secondary Special Education of the Republic of Uzbekistan, in order to implement the National Program for Personnel Training, by integrating ESD into curricula and courses of both an independent educational discipline and integrated into other traditions ionic disciplines [7]. As President Sh.M. Mirziyoyev noted, "Today in the field of education and upbringing, a new time is coming in the life of our children. Filling it with new, even deeper meaning and content, achieving national progress depends only on ourselves, on the unity and solidarity of our people, on our tireless, hard work" [8].The importance of discussion is on how to approve the model of education for sustainable development. In this case, ESD acts as a model of advanced education. It is clear that modern education cannot become ESD in a very short period of time, but in principle it is clear that in the temporal dimension it should appear earlier than SD itself on a global scale. Indeed, as noted in the UNECE document "Learning for the Future": "Education must play an important role in ensuring that people can live together in a way that helps ensure economic stability in society" [9, p. 734-754].However, at present, education often contributes to the formation of unsustainable lifestyles. This may occur as a result of the lack of opportunities for youth to critically analyze their lifestyle, the system of socio-economic development of the country, as a result of the reproduction of unstable models of practice. Therefore, to adjust the development process, it is necessary to reorient education towards sustainable economic development, taking into account the application of modern innovative approaches " $[10$, p. 2]. Indeed, ESD is the main mechanism for the transition to SD and thus ESD as a global process should be ahead of the establishment of a sustainable future in its "full format". This temporal feature of ESD was realized as its futurization, i.e. shift of emphasis on research and modeling of the future. And it's understandable why: the SD model is still basically a normative forecast, which has yet to be implemented. Therefore, along with other characteristics of ESD, as a feature that distinguishes a new form (model) of education from the modern (you can also call it traditional), the leading mechanism of the deployment of the educational process is highlighted. The advancing mechanism that futurizes education consists of including in the subject matter of education in the interests of SD the problems of the economic future, as well as much more accelerated (compared to other types of human "material" activities) development. That is why UNESCO believes that education for sustainable development is a process of learning what goals and objectives to set, how to justify their own innovative developments, to make profitable decisions needed to ensure the long-term future of the economy, ecology and equality of all communities. The development of future-oriented thinking, the introduction of innovation is the key task of education in the interests of SD. In this regard, in Uzbekistan, within the framework of accelerated education for young people, the innovative nature of pedagogical educational technologies is becoming an important tool in its competition with other social institutions. In the current socio-economic situation, not only the content, but also the forms, learning technologies are important for creating a positive orientation of youth towards education [11]. The development of new methods and channels of education is becoming an urgent need. Improving the quality, accessibility, effectiveness of education, its continuous and innovative nature, the growth of social mobility and youth activity, its inclusion in various educational environments make the education system an important factor in ensuring the national security of Uzbekistan [12]. 
This makes it possible to find oneself in the socio-economic sphere of activity, to master a profession, to achieve career growth, to open a business thanks to the embodiment of the enterprise, initiative and creativity of their own business plans. This is a great merit of teachers who, through their dedicated work, contribute to the development of education in the country. As President Sh.M. Mirziyoyev noted, "But the most difficult task, requiring tremendous work and responsibility, is the training of teachers and mentors with innovative, creative thinking, who train their students on the basis of the highest criteria. From this point of view, a modern teacher should be a universal specialist, not only teach, but at the same time learn on his own, that is, constantly work on himself, improve his knowledge "[13].

\section{CONCLUSION}

Thus, in the process of introducing innovative pedagogical technologies, the leading one is the modular education system aimed at the formation of joint creative professional activity of student youth, the development of students' independent thinking, the ability to make optimal decisions in practice.

Using a modular approach will allow students to be endowed with the following important competencies: operational - independently work with information, master the interactive properties of a computer with a high rate of motivation and activity in the educational process; cognitive to form and streamline the relationship of knowledge and skills. The student acquires the skills of reflection and introspection of the work performed; communicative - to form communication skills; self-education (self-improvement and development) - the acquisition of independent experience to analyze the educational material and their own activities in relation to the educational process as a whole.

The use of modern innovative pedagogical technologies in the educational process is a prerequisite for ensuring a high level of intellectual, personal and spiritual development of young people, mastering the skills of a scientific style of cognition, mastering the methodology of innovations in the professional sphere, creating a steady interest in the chosen profession and innovative areas. Innovation in education can be an important leading "economic catalyst" of the future. Moreover, without a specially organized education and enlightenment, humanity, including the younger generation, in principle, will not be able to move to sustainable economic development, to master the information world and the values of the civilization process.

\section{REFERENCES}

1. Transforming our world: the 2030 Agenda for Sustainable $\begin{array}{llccc}\text { Development, } & \text { p. } & 22 & \text { //URL: }\end{array}$ https://sustainabledevelopment.un.org/post

2. See: Incheon Declaration. Education-2030: ensuring universal inclusive and equitable quality education and lifelong learning, p.6 //URL: http://unesdoc.unesco.org/images

3. See: Khanty-Mansiysk recommendations on the implementation of the Global Program of Action on Education for Sustainable Development. International Conference on Education for Sustainable Development, p.13 //URL: http://www.geogr.msu.ru

4. A.D.Ursul. Advanced education. From modernization to futurization. Saarbrücken: Dictus Publishing,, 2015 , p. 123

5. See: Information note on the 2014 World Conference on Education for Sustainable Development, p.C.2-3 //URL: http://www.geogr.msu.ru
6. See: Tashkent resolution of the participants of the international conference "Joint actions to mitigate the consequences of the Aral disaster: new approaches, innovative solutions, investments", June 7-8, 2018

7. Uzbekistan on the way to sustainable development National Communication of 01.19.2017.http://nethash.ru

8. See: Holiday greetings of the President of Uzbekistan Shavkat Mirziyoyev of teachers and mentors of Uzbekistan on Teacher's Day September 29, 2019 https://www.togri.uz/ru

9. Ursul A.D., Ursul T.A. Global revolutions in science and education // Politics and Society, 2015, pp. 734-754

10. Ursul A.D. From modernization to futurization of education: innovative-leading processes in the interests of sustainable development // Security of Eurasia. 2008. No3, p. 2

11. Nurmuradova Sh.I. Innovative pedagogical technologies in the training of specialists by universities // Interdisciplinary research in science and education, 2014, No. 3H.http: //mino.esrae.ru

12. See: The Decree of the President of the Republic of Uzbekistan "On Additional Measures to Improve the Quality of Education in Higher Educational Institutions and Ensure Their Active Participation in Large-Scale Reforms Implemented in the Country," June 5, 2018, No. PP-3775

13.See: Holiday greetings of the President of Uzbekistan Shavkat Mirziyoyev of teachers and mentors of Uzbekistan on Teacher's Day September 29, 2019 https://www.togri.uz/ru

\section{AUTHORS PROFILE}

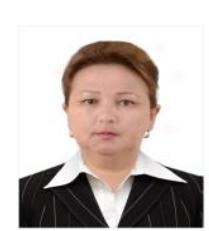

Azizakhon Abdullajonovna Usmanova Azizakhon Usmanova, Doctor of philosophy Ph.D., Docent Pedagogical and age Psychology, Head of the Social and Human Sciences Branch of the I.M.Gubkin Russian State University of Oil and Gas (NRU) in Tashkent, Republic of Uzbekistan. She graduated from the Psychological Institute of the Russian Academy of Education. She has been working in the education system for 35 years. He is currently giving lectures on Social Psychology, Cultural Studies, and the National Idea. Her specialization is related to the psychology of adolescence. She has published about 90 scientific articles in various scientific journals of the republic, as well as abroad. She made presentations on the issue of political and psychological foundations of the formation of social activity of youth of Uzbekistan in national and international conferences. She is the author of 15 textbooks and textbooks on the psychology of management. She is the head of student initiatives and startups.

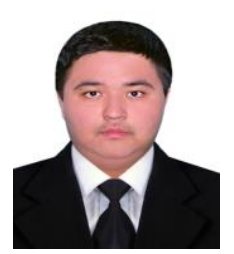

Sardorbek Abdullayevich Usmanov, 4th year student of the faculty "International Relations", University of World Economy and Diplomacy of the Republic of Uzbekistan. His research interests are related to world politics, practiced on the development of Uzbek-Chinese relations. He is the author of 10 scientific articles and abstracts on the topic under study. He made reports at republican scientific and practical conferences. He is the holder of certificates in the nomination "Best Article". He is an active member of the student club "Diplomat". 